\section{Investigation of the Relationship Between Self-Efficacy Belief and Classroom Management Skills of Preschool Teachers with Other Variables}

\author{
Döndü Neslihan Bay*
}

$\begin{array}{ll}\text { Received: } & 26 \text { September } 2019 \\ \text { Revised: } \quad & 17 \text { January } 2020 \\ \text { Accepted: } \quad 27 \text { March } 2020 \\ \text { ISSN: } 1307-9298 \\ \text { Copyright @ IEJEE } \\ \text { www.iejee.com }\end{array}$

DOI: 10.26822/iejee.2020459463

\begin{abstract}
This study aimed to determine preschool teachers' self-efficacy belief levels and their classroom management skills and to examine the relationship existing between them. The research, which was designed according to the correlational survey model, was conducted on 274 preschool teachers. Descriptive statistics, inferential statistics, and correlational statistics were used to analyze the data collected via the "Self-Efficacy Belief Scale of Pre-Service Teachers" and "Classroom Management Skills Scale for Pre-Service Teachers". The findings of the study revealed that preschool teachers' self-efficacy belief levels and classroom management skills were high, and affected by teachers' age, seniority, type of school, and the number of children in the class. In addition, the findings of the study revealed that there were positive, moderate, and strong relationships between preschool teachers' self-efficacy and professional skills and classroom management skills. The moderate positive relationship between teachers' self-efficacy belief and classroom management skills showed that the qualities achieved in these two areas affected each other.
\end{abstract}

Keywords: Preschool Teacher, Self-Efficacy Belief, Classroom Management Skills

\section{Introduction}

Self-efficacy belief appears to be the main factor in determining the causes of an individual's behavior and the changes in his/her behavior (Henson, 2001; Gençtürk, 2008). As a concept, self-efficacy belief was expressed by Bandura (1977) within the "social learning theory" as "the belief that individuals can plan, organize, and execute the actions that they need to perform a certain performance". Teachers' existing capacities that can be used in the learning process of the pupils and their belief about the sufficiency of these capacities constitute teachers' self-efficacy belief (Babaoğlan \& Korkut, 2010; Tschannen-Moran \& Woolfolk-Hoy, 2001). The knowledge, skills, and attitudes of teachers play an important role in these beliefs (Demirtaş, Cömert, \& Özer, 2011; Gokmen et al., 2016). In this context, self-efficacy belief is also the source of personal development and change that will enable the teacher to have the necessary qualities (Gömleksiz \& Serhatlıoğlu, 2013). Concurrently, self-efficacy belief level is effective in increasing motivation (Shunk, 1991) and in achieving success (YIlmaz, Tomris, \& Kurt, 2016). Therefore, self-efficacy belief level will be effective on the negative or positive attitudes of the individual towards a certain field (Şenol \& Ergün, 2015).

Educational practices, the processes of organizing classroom environment and creating a classroom atmosphere, may differ by teachers' self-efficacy belief levels. (Gibson \& Dembo, 1984; Şenol \& Ergün, 2015; Yılmaz, Gerçek, Köseoğlu, \& Soran, 2006). Teachers' self-efficacy belief has a significant impact on the development and application of different solution strategies in identifying and solving problems in the educational environment. Therefore, teachers' self-efficacy belief ensures that they perceive themselves as sufficient (Özdemir, 2008; Üstüner, Demirtaş, Cömert, \& Özer, 2009). A low self-efficacy belief level causes a decrease in pupils' learning levels due to teachers' occupational burnout (O'Neill \& Stephenson, 2011), whereas teachers with high self-efficacy belief levels appear to affect the academic achievement of the pupils (Goddard \& Goddard, 2001; Gömleksiz \& Serhatli- oglu, 2013; Senol \& Ergun, 2015; Tschannen-Moran \& Woolfolk-Hoy, 2001), their motivation, and self-efficacy belief (Babaoğlan \& Korkut, 2010; Gökmen et al., 2016; Üstüner et al., 2009) along with professional achievement. In other words, teachers increase children motivation towards learning and help them to develop positive attitudes towards themselves (Midgley-Feldlaufer \& Eccles, 1989). Studies conducted to investigate teachers' self-efficacy and its effects showed that a positive classroom atmosphere has a positive effect on children (Goddard \& Goddard, 2001; Üstüner et al., 2009). In a study conducted on 135 children receiving preschool education, Justice, Mashburn, Hamre, and Pianta (2008) concluded that there is a positive relationship between teacher self-efficacy and children's literacy skills. This can be explained with the fact that teachers with high self-efficacy belief levels have a more humanistic approach towards children and with their development in planning and organizing child-centered learning activities (Goddard \& Goddard, 2001; Guo, Shayne, Piasta, Laura, Justice, \& Kaderavek, 2010; Woolfolk-Hoy \& Hoy, 1990).

When compared, teachers with strong self-efficacy perceptions tend to use more organized and better-planned class strategies than those with low self-efficacy belief levels (Goddary, Hoy, \& Woolfolk, 2000). Therefore, there is a correlation between teachers' self-efficacy belief and classroom management skills (Woolfolk-Hoy \& Hoy, 1990). In addition to their self-efficacy belief, teachers should have the ability to exhibit classroom management skills with which they can organize the educational environment (Öztürk, 2002; Jacobson, 2003; Denizel-Güven \& Cevher, 2005; Getting \& Kohler, 2006). Classroom management is the establishment of a motivational and participatory classroom environment for ensuring the learning of children at the highest level (Sadık \& Dikici-Sığırtmaç, 2016). In other words, classroom management includes the methods and practices used to create a learning environment targeting children's behavior and thinking (Marzano, 2003). The good use of classroom management skill by the teacher has a positive effect on children's behaviors and achievements, and decreases children's unwanted 
behaviors (Akgün, Yarar, \& Dinçer, 2011; Aküzüm \& Altunhan 2017; Meehan, Cowley, Schumacher, Hauser, \& Croom, 2003; Miller, 2003; Oliver, Wehby, \& Reschly, 2011; Özdemir, 2004; Pianta, 1997; Sucuoğlu, 2008). In order for the teacher to be a good class manager, he/she should possess the knowledge of effective teaching and interventional strategies, as well as the ability to decide the appropriate action and develop new strategies when necessary (Açıkgöz, 2003). This is possible by improving the teachers' knowledge and skills in classroom management (Duman, 2008). Research showed that teachers' competencies had a significant effect on classroom management (Piwowar, Thiel, \& Ophardt, 2013; Degol \& Bachman, 2015; Denizel-Güven \& Cevher, 2005). In their study involving teachers' classroom management skills, Marzano, Marzano, and Pickering (2003) concluded that teachers' behaviors were more influential on the achievement of children than other factors, such as curriculum and school policies. Teachers who use effective classroom management strategies in the classroom have been observed to increase the pupils' self-esteem and achievement levels and to easily solve disciplinary problems (Meehan et al., 2003). In other words, during the preschool period when children are in the educational environment for the first time and begin to develop their perception of the school, the classroom management skills of the teachers have a significant effect on children's learning (Jacobson, 2003; Sadık \& Dikici-Sığırtmaç, 2016). In addition, the classroom management skills of teachers in preschool educational institutions where children with special needs have been included in mainstream education since 2009, is becoming more important (Başal, 2005).

The level of classroom management is affected by the attitudes and belief of teachers and children (Kagan, 1992). In addition, teachers' self-efficacy belief levels affect their efforts in the teaching process and their achievement of educational objectives (Henson, 2001; Tschannen-Moran \& Woolfolk-Hoy, 2001). Lorsbach and Jinks (1999) concluded that teachers with high self-efficacy belief levels possess better time management skills, which is one of the classroom management strategies. Büyükduman (2006) reported that self-efficacy belief has a significant effect on the ability to create a conducive educational environment, which is considered one of the classroom management skills. Woolfolk-Hoy (2000) stated that possessing a high self-efficacy belief level leads teachers to be more willing to practice and be more loyal to the profession. Similarly, studies revealed that there is a relationship between teacher self-efficacy belief and classroom management skills (Woolfolk-Hoy \& Hoy, 1990; Savran \& Çakıroğlu, 2003). Success in education is possible with the success of teachers. This success can be achieved by ensuring that teachers have high self-efficacy belief levels about their duties and responsibilities (Yılmaz, Köseoğlu, Gerçek, \& Soran, 2004). In this regard, considering the effect of teachers on the educational process, it is important to analyze teachers' self-efficacy belief and classroom management skills and the factors affecting these beliefs and skills.

Previous studies examined teachers' self-efficacy belief levels by some variables (Guo et al., 2010; Gömleksiz \& Serhatlıoğlu, 2013; Kadim, 2013; Şenol \& Ergün, 2015; Yılmaz et al., 2016; Gökmen et al., 2016). Similarly, some studies revealed that many variables affected the classroom management skills of preschool teachers (Filcheck, Mcneil, Greco, \& Bernard, 2004; Denizel Guven \& Cevher, 2005; Gezgin, 2009; Tal, 2010; Akgün et al., 2011; Carlson, Tiret, Bender, \& Benson, 2011; Nur 2012; Yeşilay Daşıran, 2013; Keles, 2013; Degol \& Bachman, 2015; Dinçer \& Akgün 2015; Adıgüzel, 2016; Toran \& Gençgel Akkuş, 2016; Zembat, Tunçeli, \& Akşin Yavuz, 2017; Sadık \& Dikici Sığırtmaç, 2016; Aküzüm \& Altunhan, 2017; Metin, Aydoğan, Kavak, \& Mercan, 2017; Ekici, Günhan, \& Anılan, 2017; Şahin-Sak, Sak, \& Tezel-Şahin, 2018)
Regarding the studies conducted in Turkey, only one study investigated the relationship between preschool teachers self-efficacy belief levels and classroom management perception levels (Toran, 2019). It is thought that determining the relationship between self-efficacy belief and classroom management skill perception of preschool teachers will fill the gap in the field and contribute to the teacher training programs to increase the quality of preschool teachers.

\section{Purpose of the Study}

The main purpose of this study was to analyze the relationship between preschool teachers' classroom management skills and self-efficacy belief levels. The following questions were addressed within this framework:

1. What is the level of classroom management skills and self-efficacy belief of preschool teachers?

2. Do the classroom management skills and self-efficacy belief of preschool teachers differ by their demographic characteristics (age, education level, seniority, type of school, and the number of children in the class)?

3. Is there a relationship between the self-efficacy belief of preschool teachers and their classroom management skills (professional skills and teacher-child interaction)?

\section{Method}

This quantitative study was conducted using the correlational survey model. According to Karasar (2003, p. 81), "correlational survey model is a research model aiming to determine whether there is a relationship between two or more variables and/or the extent of the relationship".

\section{Participations}

The study population comprised 576 preschool teachers from the central districts of Eskişehir; 257 of them worked in Tepebaşı, whereas 319 worked in Odunpazarı. Using the stratified sampling technique, from purposive sampling methods, 275 teachers were chosen from the study population; the results obtained from 274 teachers were reported after the data analysis. In the selection of the sample, firstly, the equation stated by Büyüköztürk, Çakmak, Akgün, Karadeniz, and Demirel (2018) was used to select the sample size that represented the population; the minimum sample size representing 576 teachers with a 95\% confidence interval was found to be 230 . Afterward, kindergartens in primary schools and preschools in Tepebaşı and Odunpazarı were identified, and sampling was performed according to the weight of schools in the districts. In this way, it was ensured that the sample represented the population both quantitatively and qualitatively. The characteristics of the teachers are summarized in Table 1.

As shown in Table 1, 11 characteristics of 274 preschool teachers participating in the research were considered. Most, $98.9 \%$ $(n=271)$, of the preschool teachers were female, and 1.1\% $(n=3)$ were male. As $12.4 \%(n=34)$ of the teachers were under 30 years, $30.3 \%(n=83)$ were $30-34$ years old, $29.9 \%(n$ $=82$ ) were $35-39$ years old, and $27.4 \%(n=75)$ were over 40 years. The distributions of the teachers according to seniority were checked and it was found that $11.3 \%(n=31)$ had $0-5$ years, $31.0 \%(n=81)$ had $6-10$ years, and $57.7 \%(n=158)$ had at least 11 years of work experience. Of the 274 teachers whose opinions were taken within the scope of the study, 30.7\% ( $n=$ 84) graduated from open education, whereas $69.3 \%(n=190)$ graduated from formal education. The results depicted that majority of the teachers $(93.1 \% ; n=255)$ had a bachelor's de- 
Table 1. Characteristics of the Teachers

\begin{tabular}{|c|c|c|c|c|}
\hline Demographic characteristics & Sub-categories & N & $\%$ & Overall \\
\hline \multirow{2}{*}{ Gender } & Female & 271 & 98.9 & \multirow{2}{*}{274} \\
\hline & Male & 3 & 1.1 & \\
\hline \multirow{4}{*}{ Age } & Less than 30 & 34 & 12.4 & \multirow{4}{*}{274} \\
\hline & 30-34 years old & 83 & 30.3 & \\
\hline & 35-39 years old & 82 & 29.9 & \\
\hline & Over 40 years old & 75 & 27.4 & \\
\hline \multirow{3}{*}{ Professional seniority } & $0-5$ years & 31 & 11.3 & \multirow{3}{*}{274} \\
\hline & $6-10$ years & 81 & 31 & \\
\hline & 11 years and more & 158 & 57.7 & \\
\hline \multirow{2}{*}{ Type of school graduated from } & Open education & 84 & 30.7 & \multirow{2}{*}{274} \\
\hline & Formal education & 190 & 69.3 & \\
\hline \multirow{3}{*}{ Education level } & Under-graduate & 14 & 4.4 & \multirow{3}{*}{274} \\
\hline & Graduate & 255 & 93.1 & \\
\hline & Post-graduate & 7 & 2.6 & \\
\hline \multirow{2}{*}{ Type of school } & Kindergarten & 108 & 39.4 & \multirow{2}{*}{274} \\
\hline & Preschool & 166 & 60.6 & \\
\hline \multirow{3}{*}{ Age group of the children in the class } & Three years old & 13 & 4.7 & \multirow{3}{*}{274} \\
\hline & Four years old & 67 & 24.5 & \\
\hline & Five years old & 194 & 70.8 & \\
\hline \multirow{2}{*}{ Class size } & 15 or less & 46 & 16.8 & \multirow{2}{*}{274} \\
\hline & 16 or more & 228 & 83.2 & \\
\hline \multirow{2}{*}{ Working time } & Full-Day & 270 & 98.5 & \multirow{2}{*}{274} \\
\hline & Half-Day & 4 & 1.5 & \\
\hline \multirow{2}{*}{ Availability of an assistant staff } & Available & 136 & 49.6 & \multirow{2}{*}{274} \\
\hline & Not available & 138 & 50.4 & \\
\hline \multirow{2}{*}{ Working status } & Permanent & 250 & 91.2 & \multirow{2}{*}{274} \\
\hline & Contracted / paid & 24 & 8.8 & \\
\hline
\end{tabular}

gree; $4.4 \%(n=14)$ had an associate degree, and $2.6 \%(n=$ 7) had a master's degree. A total of $39.4 \%(n=108)$ of teachers worked in primary schools, whereas $60.6 \%(n=166)$ of teachers worked in preschool. Regarding the age groups of the children in their classrooms, $4.7 \%(n=13)$ of the teachers had 3-year-old, 24.5\% ( $n=67)$ had 4-year-old, and $70.8 \%$ $(n=194)$ had 5 -year-old children. Whereas $16.8 \%(n=46)$ of the teachers had at most 15 children in their classroom, $83.2 \%(n=228)$ had at least 16 children. The majority of teachers $(98.5 \% ; n=270)$ were working half-day, whereas $1.5 \%(n=4)$ were working full time. Concerning availability of assistant staff, $49.6 \%(n=136)$ of the teachers stated that they had assistant, and $50.4 \%(n=138)$ did not. Most, $91.2 \%$ $(n=250)$, of the teachers work permanently, and $8.8 \%(n=$ $24)$ of them work on contractual base or paid.

\section{Data Collection Method}

Demographic and Profession Information Form: It consists of the items prepared by the researcher to determine gender, age, seniority, education level, type of school graduated from, age group of children in their class, the number of children in their class, working time and status, and the availability of an assistant staff.

\section{Classroom management skills scale for preschool teachers}

The scale, which was developed by Dinçer and Akgün (2015) for evaluating classroom management skills of preschool teachers, is a 5-point Likert-type scale with 40 items. The scale has the following two sub-dimensions: teachers' pro- fessional skills and teacher-child interaction. The validity and reliability of the "Classroom Management Skills Scale for Preschool Teachers" were tested by applying it to 520 preschool teachers. As a result of the exploratory factor analysis, the factor loads related to the professional skills sub-dimension were found to be between .301 and .646, whereas factor loads of the teacher-child interaction sub-dimension were between .405 and .677. Accordingly, it was concluded that the scale met the accepted validity values (Dinçer \& Akgün, 2015). The reliability of the answers given for the "Classroom Management Skills Scale for Preschool Teachers" were computed via test-retest and Cronbach's alpha coefficient, which was $a=.88$ for the professional skills sub-dimension, $a=$ .70 for the teacher-child interaction sub-dimension, and $a=$ .83 for the whole scale. Test-retest reliability coefficient was found to be $r=.87$ for the professional skills sub-dimension, $r=.83$ for teacher-child interaction sub-dimension, and $r$ $=.91$ for the overall score, which showed that the scale met the reliability criteria (Dinçer \& Akgün, 2015).

The scale was applied to 274 teachers to determine the classroom management skills of preschool teachers working in the central districts of Eskişehir. Cronbach's alpha coefficient was calculated to determine the reliability of the teachers' responses to the scale. The coefficient was found to be $\alpha=.929$ for the professional skills dimension, $a=.822$ for the teacher-child interaction dimension, and $a=.902$ for the whole scale. The calculated values indicate that the responses of the preschool teachers to the scale items are reliable. 
Table 2. Descriptive Statistics

\begin{tabular}{|c|c|c|c|c|c|c|c|}
\hline Scale & Sub-dimension & $N$ & Minimum & Maximum & Mean & $S D$ & $\begin{array}{l}\text { Item aver- } \\
\text { age }\end{array}$ \\
\hline \multicolumn{2}{|c|}{ Self-efficacy belief scale } & 274 & 129.00 & 185.00 & 169.53 & 13.92 & 4.58 \\
\hline \multicolumn{2}{|r|}{ Learning-teaching process } & 274 & 33.00 & 45.00 & 41.61 & 3.28 & 4.62 \\
\hline \multicolumn{2}{|r|}{ Communication } & 274 & 24.00 & 35.00 & 32.21 & 2.74 & 4.60 \\
\hline \multicolumn{2}{|r|}{ a } & 274 & 16.00 & 25.00 & 22.55 & 2.27 & 4.51 \\
\hline \multicolumn{2}{|r|}{ Planning } & 274 & 20.00 & 30.00 & 27.34 & 2.62 & 4.56 \\
\hline \multicolumn{2}{|r|}{ Organization of learning environments } & 274 & 18.00 & 25.00 & 22.99 & 2.01 & 4.60 \\
\hline \multicolumn{2}{|r|}{ Classroom management } & 274 & 17.00 & 25.00 & 22.87 & 2.06 & 4.57 \\
\hline \multicolumn{2}{|c|}{ Classroom management skills scale } & 274 & 153.00 & 200.00 & 184.13 & 11.72 & 4.60 \\
\hline \multicolumn{2}{|r|}{ Professional skills } & 274 & 115.00 & 155.00 & 143.30 & 10.35 & 4.62 \\
\hline \multicolumn{2}{|r|}{ Teacher-child interaction } & 274 & 29.00 & 45.00 & 40.83 & 4.24 & 4.54 \\
\hline
\end{tabular}

\section{Self-efficacy belief scale of preschool teachers}

The "Self-Efficacy Belief Scale of Preschool Teachers" developed by Tepe and Demir (2012) is a 5-point Likert-type scale consisting of 37 items. Tepe and Demir (2012) applied the scale to 862 preschool teachers for the validity and reliability study, and conducted exploratory factor analysis on the data. As a result of the analysis, it was found that the one-dimensional version of the 37 -item scale explained $45.78 \%$ of the total variance, whereas the multi-dimensional version, formed by six factors, explained $65 \%$ of the total variance. The six factors in the scale were examined in terms of content; the first factor was named as "Learning-Teaching Process", the second factor "Communication Skills", the third factor "Parental Involvement", the fourth factor "Planning", the fifth factor "Organization of Learning Environments", and the sixth factor "Class Management". Item factor loads varied between .54 and .71 in the first factor, .55 and .78 in the second factor, .70 and .80 in the third factor, .56 and .71 in the fourth factor, .57 and .68 in the fifth factor, and .45 and .69 in the sixth factor. Concurrently, confirmatory factor analysis was performed for single and multidimensional forms of the scale. The calculated model-fit values for the single dimensional form $\left(X^{2} / s d\right)=3.11, p=$ .00 , comparative fit index $(\mathrm{CFI})=.95$, normed fit index $(\mathrm{NFI})=$ .93 , standardized root mean square residual $(S R M R)=.34$, root mean square error of approximation (RMSEA) $=.05$, goodness of fit index $(\mathrm{GFI})=.92$, adjusted goodness of fit index $(\mathrm{AGFI})=$ .88 and multidimensional form chi-square / degree of freedom $\left(X^{2} / s d\right)=3.13, p=.00, \mathrm{CFI}=.94, \mathrm{NFI}=.92, \mathrm{SRMR}=.52$, RMSEA $=.04, \mathrm{GFI}=.92, \mathrm{AGFI}=.90$ ) also indicate that the models were validated. The reliability of the answers given by the teachers to the scale items was calculated using Cronbach's alpha coefficient and combined reliability coefficient (CRC). Alpha values were calculated as $\alpha=.91$ for the learning-teaching process dimension, $a=.90$ for the communication dimension, $a=.90$ for the parental involvement dimension, $\alpha=.87$ for the planning dimension, $a=.88$ for the organization of learning environments dimension, and $\alpha=.87$ for the class management dimension. The combined reliability coefficient was found to vary between .95 and .97 (Tepe \& Demir, 2012).

The reliability of the answers provided by the preschool teachers who participated in this study to the self-efficacy belief scale was also checked using Cronbach's alpha coefficient. As a result of the computations, alpha values were calculated as $a=.843$ for the learning-teaching process dimension, $a=.816$ for the communication dimension, $a=.774$ for the parental involvement dimension, $a=.862$ for the planning dimension, $a=$ .764 for the organization of learning environments dimension, and $a=.791$ for the class management dimension. In other words, preschool teachers working in Eskişehir district centers provided reliable answers to the scale items.
Data Analysis

A total of 275 preschool teachers were contacted within the scope of the research. After the answers of the teachers were digitized, the data set was checked for missing values, but none was found. Then, the lowest-highest values were calculated, and incorrect data entries were corrected. After reviewing the data set, the overall and sub-dimension scores were calculated for each scale. The $z$-statistic of the scores was calculated, and an observation, showing three values, was excluded from the data set. Skewness and kurtosis coefficients for the remaining 274 teachers were calculated, and histogram graphs were drawn. Regarding the histogram graphs with coefficient values between -1 and +1 , it was observed that the data sets did not start at 0 and were normally distributed. The skewness coefficient of teachers' self-efficacy total score was found to be -.587 with a kurtosis coefficient of -.691; skewness coefficient of teachers' class management score was found to be -.722 with a kurtosis coefficient of -.413 . Similar coefficient calculations were performed for the sub-dimensions as well.

After determining the distribution of the data set, descriptive statistics were calculated for analyzing the data. Then, parametric and non-parametric tests were conducted according to the demographic characteristics of the teachers to verify if the data met the assumptions. The results were interpreted by taking level of significance $(p)$ as .05. The Pearson correlation coefficient was also calculated to determine the relationship between teachers' self-efficacy and classroom management skills.

\section{Findings}

The findings obtained in this section are given in order of the research questions.

Findings About Classroom Management Skills and Self-Efficacy Belief Levels of Preschool Teachers

Descriptive statistics were calculated to determine the level of self-efficacy belief and classroom management skills of preschool teachers, and the results are shown in Table 2.

The review of Table 2 shows that the self-efficacy belief scores of the preschool teachers working in the central districts of Eskişehir varied between 129.00 and 185.00 , and the average was calculated as 169.53 ( \pm 13.92 ). It can be seen that teachers' classroom management skill scores varied between 153.00 and 200.00 , and the average was calculated as 184.13 $( \pm 11.72)$.

As the number of items in the scales and their sub-dimensions were different, each average was scaled in the range of 1 to 5 by proportioning the overall score to the number of items. 
Table 3. Difference Statistics of the Teachers According to Age

\begin{tabular}{|c|c|c|c|c|c|c|}
\hline Scale & Age & $N$ & Mean & $S D$ & Difference statistics & $p$ \\
\hline \multirow{4}{*}{ Self-efficacy belief } & Less than 30 & 34 & 164.09 & 16.26 & \multirow{4}{*}{$X_{(3)}^{2}=11.910 *$} & \multirow{4}{*}{.008} \\
\hline & 30-34 years old & 83 & 168.78 & 12.10 & & \\
\hline & 35-39 years old & 82 & 169.38 & 14.38 & & \\
\hline & Over 40 years old & 75 & 172.99 & 13.48 & & \\
\hline \multirow{4}{*}{ Classroom management skills } & Less than 30 & 34 & 181.09 & 13.59 & \multirow{4}{*}{$F_{(3.273)}=1.533^{* *}$} & \multirow{4}{*}{.206} \\
\hline & 30-34 years old & 83 & 184.31 & 10.87 & & \\
\hline & 35-39 years old & 82 & 183.45 & 12.01 & & \\
\hline & Over 40 years old & 75 & 186.04 & 11.29 & & \\
\hline
\end{tabular}

Table 4. Difference Statistics of the Teachers According to Seniority

\begin{tabular}{|c|c|c|c|c|c|c|}
\hline Scale & Seniority & $N$ & Mean & $S D$ & Difference statistics & $p$ \\
\hline \multirow{3}{*}{ Self-efficacy belief } & $0-5$ years & 31 & 165.26 & 14.62 & \multirow{3}{*}{$F_{(2.273)}=2.391^{*}$} & \multirow{3}{*}{.093} \\
\hline & $6-10$ years & 85 & 168.61 & 13.38 & & \\
\hline & $11+$ years & 158 & 170.86 & 13.94 & & \\
\hline \multirow{3}{*}{ Classroom management skills } & $0-5$ years & 31 & 181.97 & 12.04 & \multirow{3}{*}{$F_{(2.273)}=1.167^{*}$} & \multirow{3}{*}{.313} \\
\hline & $6-10$ years & 85 & 183.31 & 12.48 & & \\
\hline & $11+$ years & 158 & 184.99 & 11.22 & & \\
\hline
\end{tabular}

*(One-way ANOVA) test

Table 5. Difference Statistics of the Teachers According to the Type of School Graduated from

\begin{tabular}{|c|c|c|c|c|c|c|}
\hline Scale & Type of School & $N$ & Mean & $S D$ & Difference statistics & $p$ \\
\hline \multirow{2}{*}{ Self-efficacy belief } & Open education & 84 & 169.29 & 13.69 & \multirow{2}{*}{$t_{(272)}=.192$} & \multirow{2}{*}{.848} \\
\hline & Formal education & 190 & 169.64 & 14.05 & & \\
\hline \multirow{2}{*}{ Classroom management skills } & Open education & 84 & 184.23 & 11.45 & \multirow{2}{*}{$t_{(272)}=.92$} & \multirow{2}{*}{.927} \\
\hline & Formal education & 194 & 184.08 & 11.87 & & \\
\hline
\end{tabular}

* Independent samples t-test

For example, the average score (169.53) that teachers received from the self-efficacy scale was based on 37 items; thus, it was divided by 37; whereas the average of the teaching-learning process sub-dimension was divided by 9 . Based on Tekin's (2002) "range/number of categories" equality, the average of 1-5 scale scores was interpreted as:

- Scores between 1.0 and 2.3 are low;

- Scores between 2.3 and 3.7 are moderate;

- Scores between 3.7 and 5.0 are high (In Likert-type scales, the levels are accepted to be higher as the scores approach 5.00, and lower as they approach 1.00).

In line with this information, it was determined that preschool teachers working in the central districts of Eskişehir had high levels of self-efficacy belief (4.58) and classroom management skills (4.60). The scores that pre-service teachers received from the sub-dimensions of the self-efficacy belief scale were also found to be high: learning-teaching process (4.62), communication (4.60), organization of learning environments (4.60), classroom management (4.57), planning (4.56), and parental involvement (4.51). Similarly, it was found that teachers' perceptions about the sub-dimensions of classroom management skills, namely professional skills (4.62) and teacher-child interaction (4.54), were also high.

Findings Related to Differentiation of Self-Efficacy Belief and Classroom Management Skills of Preschool Teachers According to Demographic Characteristics

Difference statistics were calculated to determine whether the self-efficacy belief and classroom management skills of

the preschool teachers differ significantly according to the demographic characteristics (age, seniority, type of school graduated from, type of school in which they work, number of children in their classrooms, availability of assistants, and working status). Normality and homogeneity of variances were tested before the calculations, and parametric and non-parametric statistics were used. The results according to the ages of the teachers are shown in Table 3.

As seen in Table 3, preschool teachers' self-efficacy belief significantly differs by age $\left(X^{2}{ }_{(3)}=11.910 ; p<.05\right)$. As a result of the multiple comparison ANOVA test, which was performed to identify the source of the difference, it was found that self-efficacy belief levels of teachers older than 40 years were significantly higher than those of teachers younger than 30 years. Teachers' self-efficacy belief levels in the learning-teaching process, communication, planning, and organization of the learning environment showed no significant difference by age $(p>.05)$, whereas parental involvement and classroom management self-efficacy showed significant differences $(p<.05)$. As a result of the multiple comparison tests, it was found that the self-efficacy perception levels of teachers aged at least 40 years for parental involvement and classroom management were significantly higher than those of teachers under the age of 30 years. Concurrently, it was found that 35-39-year-old teachers' self-efficacy belief levels about organizing the learning environment were higher than those of teachers younger than 30 years.

Table 3 reveals that the classroom management skills of preschool teachers did not show a significant difference by age $\left(F_{(3.273)}=1.533 ; p>.05\right)$. Teachers' perceived professional skills and teacher-child interaction skills did not vary significantly $(p>.05)$. 
Table 6. Difference Statistics of the Teachers According to the Type of School in which They Work

\begin{tabular}{|c|c|c|c|c|c|c|}
\hline Scale & Type of School & N & Mean & $S D$ & Difference statistics & $p$ \\
\hline \multirow{2}{*}{ Self-efficacy belief } & Kindergarten & 108 & 172.78 & 13.10 & \multirow{2}{*}{$t_{(272)}=3.167$} & \multirow{2}{*}{.002} \\
\hline & Preschool & 166 & 167.42 & 14.07 & & \\
\hline \multirow{2}{*}{ Classroom management skills } & Kindergarten & 108 & 186.28 & 10.85 & \multirow{2}{*}{$t_{(272)}=2.471$} & \multirow{2}{*}{.014} \\
\hline & Preschool & 166 & 182.73 & 12.09 & & \\
\hline
\end{tabular}

*Independent samples t-test

Table 7. Difference Statistics of the Teachers According to the Children in the Class

\begin{tabular}{clrrrrrr}
\hline Scale & Number of children & $N$ & Mean & $S D$ & Difference statistics & $p$ \\
\hline \multirow{2}{*}{ Self-efficacy belief } & 15 or less & 46 & 172.78 & 14.93 & \multirow{2}{*}{$t_{(272)}=1.744$} & .082 \\
\cline { 2 - 6 } & 16 or more & 228 & 168.87 & 13.65 & & \\
\hline \multirow{2}{*}{ Classroom management skills } & 15 or less & 46 & 184.61 & 11.80 & $t_{(272)}=.304$ & .761 \\
\cline { 2 - 7 } & 16 or more & 228 & 184.03 & 11.73 & & \\
\hline
\end{tabular}

*Independent samples t-test

Table 8. Difference Statistics of the Teachers According to the Availability of Assistant Staff in Their Classrooms

\begin{tabular}{|c|c|c|c|c|c|c|}
\hline Scale & Assistant Staff & N & Mean & $S D$ & Difference statistics & $p$ \\
\hline \multirow{2}{*}{ Self-efficacy belief } & Available & 136 & 171.99 & 13.36 & \multirow[b]{2}{*}{$t_{(272)}=2.940$} & \multirow{2}{*}{.004} \\
\hline & Not available & 138 & 167.11 & 14.08 & & \\
\hline \multirow{2}{*}{ Classroom management skills } & Available & 136 & 185.54 & 12.13 & \multirow{2}{*}{$t_{(272)}=1.985$} & \multirow{2}{*}{.048} \\
\hline & Not available & 138 & 182.74 & 11.18 & & \\
\hline
\end{tabular}

*Independent samples t-test

Table 4 depicted observed that self-efficacy belief levels of preschool teachers did not show a significant difference by seniority $\left(F_{(2.273)}=2.391 ; p>.05\right)$. It was also found that the self-efficacy belief of teachers for learning-teaching process, communication, parental involvement, planning, organization of the learning environment, and classroom management did not differ significantly $(p>.05)$.

Similarly, as Table 4 shows the classroom management skills of preschool teachers did not show a significant difference by seniority $\left(F_{(2.273)}=1.167 ; p>.05\right)$. It was also found that teachers' perceived professional skills and teacher-child interaction skills did not vary significantly $(p>.05)$.

As Table 5 reveals self-efficacy belief levels of preschool teachers did not show a significant difference by the type of school they graduated from $\left(t_{(272)}=.192 ; p>.05\right)$. Similarly, self-efficacy belief levels of the teachers for learning-teaching process, communication, parental involvement, planning, organization of the learning environment, and classroom management did not differ significantly $(p>.05)$.

As can be observed in Table 5, the classroom management skills of preschool teachers did not show a significant difference by the type of school graduated from $\left(t_{(272)}=.092 ; p>\right.$ .05 ). It was found that teachers' perceived professional skills and teacher-child interaction skills did not vary significantly ( $p$ $>$.05).

As observed in Table 6, self-efficacy belief of the preschool teachers who work in the central districts of Eskişehir significantly differs by the type of school in which they work ( $t_{(272)}$ $=3.167 ; p<.05$ ). The review of the average scores showed that the self-efficacy belief levels of teachers working in primary schools were significantly higher than those of teachers working in the kindergarten. It was also found that teachers' self-efficacy for parental involvement did not show a significant difference $(p>.05)$; however, the self-efficacy belief levels of the teachers for the organization of the learning environment, learning-teaching process, communication, planning, and classroom management differed significantly $(p>.05)$. It was found that the self-efficacy belief levels of the teachers working in primary schools were significantly higher than those of the teachers working in the kindergarten.
Regarding the information in Table 6, it can be observed that the classroom management skills of the teachers showed a significant difference by the type of school in which they work $\left(t_{(272)}=2.471 ; p<.05\right)$. According to the average scores, it was found that the perceived classroom management skills of teachers who work in primary schools were significantly higher than those of teachers who work in kindergarten. Whereas there was no significant difference in teacher-child interaction skills $(p>.05)$ by the type of school in which they work, it was found that there was a significant difference in professional skills $(p<.05)$. Similarly, it was found that the perceived professional skills of teachers who work in primary schools were significantly higher than those of teachers working in kindergarten.

Regarding the information in Table 7, it is observed that self-efficacy belief levels of preschool teachers did not show a significant difference by the number of children in the class $\left(t_{(272)}=1.744 ; p>.05\right)$. Similarly, self-efficacy belief levels of teachers for learning-teaching process, communication, parental involvement, planning, and organization of the learning environment did not differ significantly according to the number of children in the class $(p>.05)$; however, their self-efficacy belief levels related to classroom management differed significantly $(p<.05)$. When average scores were reviewed, it was found that classroom management self-efficacy belief levels of the teachers who had at most 15 children in their class were significantly higher than those who had at least 16 children.

Table 7 showed that the classroom management skills of preschool teachers did not show a significant difference by the number of children in the class $\left(t_{(272)}=.304 ; p>.05\right)$. It was found that teachers' perceived professional skills did not vary significantly by the number of children in the class $(p>.05)$; however, teacher-child interaction skills were found to be different $(p<.05)$. The review of the average scores showed that the teacher-child interaction skill scores of the teachers who had at least 16 children were significantly higher than those who had at most 15 children in their classes.

As Table 8 reveals self-efficacy belief levels show a significant difference by the availability of assistant staff $\left(t_{(272)}=2.940\right.$; $p<.05)$. The review of the average scores revealed that the self-efficacy belief levels of teachers who had an assistant staff 
Table 9. Difference Statistics of the Teachers According to Working Status

\begin{tabular}{clrrrrr}
\hline Scale & Working Status & $N$ & Mean & SD & Difference statistics & $p$ \\
\hline \multirow{2}{*}{ Self-efficacy belief } & Permanent & 250 & 143.62 & 10.10 & \multirow{2}{*}{$z=.809^{*}$} & .002 \\
\cline { 2 - 5 } & Contracted / paid & 24 & 139.88 & 12.44 & & \\
\hline \multirow{2}{*}{ Classroom management skills } & Permanent & 250 & 40.81 & 4.35 & \multirow{2}{*}{$z=.993^{*}$} & .014 \\
\cline { 2 - 5 } & Contracted / paid & 24 & 41.08 & 2.98 & & \\
\hline *Mann Whitney Utest
\end{tabular}

* Mann Whitney U test

Table 7. Difference Statistics of the Teachers According to the Children in the Class

\begin{tabular}{|c|c|c|c|c|}
\hline Scale & Values & Professional skills & Teacher-child interaction & Class management skill \\
\hline \multirow{3}{*}{ Learning-teaching process } & $r$ & $.607^{* *}$ & $.146^{*}$ & $.588^{\star \star}$ \\
\hline & $p$ & .000 & .016 & .000 \\
\hline & N & 274 & 274 & 274 \\
\hline \multirow{3}{*}{ Communication } & $r$ & $.628^{* *}$ & .104 & $.592^{* *}$ \\
\hline & $p$ & .000 & .085 & .000 \\
\hline & N & 274 & 274 & 274 \\
\hline \multirow{3}{*}{ Parental involvement } & $r$ & $.592^{\star *}$ & .071 & $.549^{\star *}$ \\
\hline & $p$ & .000 & .238 & .000 \\
\hline & N & 274 & 274 & 274 \\
\hline \multirow{3}{*}{ Planning } & $r$ & $.658^{* *}$ & .104 & $.619^{* *}$ \\
\hline & $p$ & .000 & 086 & .000 \\
\hline & N & 274 & 274 & 274 \\
\hline \multirow{3}{*}{ Organization of learning environment } & $r$ & $.635^{* *}$ & $.130^{*}$ & $.608^{\star *}$ \\
\hline & $p$ & .000 & .031 & .000 \\
\hline & N & 274 & 274 & 274 \\
\hline \multirow{3}{*}{ Classroom management } & $r$ & $.657^{\star \star}$ & .083 & $.610^{\star *}$ \\
\hline & $p$ & .000 & 173 & .000 \\
\hline & N & 274 & 274 & 274 \\
\hline \multirow{3}{*}{ Self-efficacy (overall) } & $r$ & $.727^{\star *}$ & $.125^{*}$ & $.687^{\star *}$ \\
\hline & $p$ & .000 & 039 & .000 \\
\hline & N & 274 & 274 & 274 \\
\hline
\end{tabular}

${ }^{*} p<.05 ;{ }^{* *} p<.01$

were significantly higher than those of the teachers who had no assistant staff. It was found that teachers' self-efficacy levels for parental involvement did not show a significant difference by the availability of assistant staff ( $p>.05)$; however, the self-efficacy belief levels of the teachers for the organization of the learning environment, learning-teaching process, communication, planning, and classroom management differed significantly $(p<.05)$. It was found that the self-efficacy belief levels of teachers who had assistant staff were significantly higher than those of teachers who did not.

Table 8 indicates that the classroom management skills of the teachers showed a significant difference by the availability of assistant staff $\left(t_{(272)}=1.985 ; p<.05\right)$. According to the average scores, it was found that the perceived classroom management skills of teachers who had assistant staff were significantly higher than those of teachers who did not. It was found that there was no significant difference in teacher-child interaction skills $(p>.05)$ according to the availability of assistant staff, whereas their perceived professional skills showed a significant difference $(p<.05)$. Similarly, it was found that the perceived professional skills of teachers who had assistant staff were significantly higher than those who did not.

According to the information in Table 9, self-efficacy belief levels of the teachers did not show a significant difference by working status $(z=.809 ; p>.05)$. Similarly, self-efficacy belief of the teachers for learning-teaching process, communication, parental involvement, planning, organization of the learning environment, and classroom management did not differ significantly according to working status $(p>.05)$.

Table 9 shows that the classroom management skills of preschool teachers did not show a significant difference by working status $(z=.993 ; p>.05)$. It was found that teachers' professional skills and teacher-child interaction did not vary significantly according to working status ( $p>.05)$.

Findings About the Relationship Between Classroom Management Skills and Self-Efficacy Belief of Preschool Teachers

The Pearson correlation coefficient was calculated to determine the relationships between the classroom management skills and self-efficacy belief of preschool teachers working in the central districts of Eskişehir. The results are shown in Table 10

Regarding the sub-dimensions of the classroom management skills of preschool teachers displayed in Table 10, it is observed that there is a positive and strong relationship between preschool teachers' perceived professional skills and their self-efficacy belief levels $(r=.727 ; p<.01)$.

It was found that there are positive and moderate relationships between teachers' professional skills and some of the sub-dimensions of self-efficacy belief, namely planning $(r=$ $.658 ; p<.01)$, classroom management $(r=.657 ; p<.01)$, organization of the learning environment $(r=.635 ; p<.01)$, 
communication ( $r=.628 ; p<.01)$, learning-teaching process $(r=.607 ; p<.01)$, and parental involvement $(r=.592 ; p<.01)$.

Table 10 show that there is a positive but weak relationship between teacher-child interaction, which is one of the sub-dimensions of classroom management skills, and self-efficacy belief $(r=.125 ; p<.05)$. It was found that there were positive and weak relationships between perceived teacher-child interaction skills and learning-teaching process $(r=.146 ; p<$ $.05)$ and organization of the learning environment $(r=.130 ; p$ $<0.05$ ), which are among the sub-dimensions of self-efficacy belief.

The findings of the study revealed that there is no significant relationship between preschool teachers' teacher-child interaction skills and communication $(r=.104 ; p>.05)$, planning $(r$ $=.104 ; p>.05)$, classroom management $(r=.083 ; p>.05)$, and parental involvement $(r=.071 ; p>.05)$.

As it is observed in Table 10, it was found that there was a positive and moderate relationship between the classroom management skills and self-efficacy of preschool teachers ( $r$ $=.687 ; p<.01)$.

Positive and moderate relationships were identified between teachers' perceived classroom management skills and planning $(r=.619 ; p<.01)$, classroom management $(r=.610 ; p<$ $.01)$, organization of the learning environment $(r=.608 ; p<$ $.01)$, communication $(r=.592 ; p<.01)$, learning-teaching process $(r=.588 ; p<.01)$, and parental involvement $(r=.549 ; p<$ $.01)$.

\section{Discussion, Conclusion and Suggestions}

Data were collected from 274 preschool teachers to examine the relationship between classroom management skills and self-efficacy belief of preschool teachers and the differentiation of self-efficacy belief and classroom management skill levels of teachers by some demographic characteristics. The relationship between teachers' self-efficacy belief and classroom management skills was analyzed by using descriptive statistics, difference statistics, and correlational statistics. The evaluation of the results of preschool teachers' classroom management skills and self-efficacy belief, which is the first sub-goal of the study, revealed that teachers' self-efficacy belief levels (4.58) and classroom management skills (4.60) were high. Research revealed some similar findings with this study. Babaoğlan and Korkut (2010) examined 401 class teachers to determine their self-efficacy perceptions and classroom management skills and they found that teachers' self-efficacy perceptions and classroom management skills were high. The study of Gömleksiz and Serhatlıoglu (2013) examined self-efficacy belief levels of preschool teachers and found that the self-efficacy levels of teachers were high. Gökmen et al. (2016) studied 346 preschool teachers to identify their HighScope approach and self-efficacy belief levels. and found that preschool teachers had high levels of self-efficacy belief. Results indicating high self-efficacy belief levels of the teachers in other studies (Yılmaz \& Çokluk-Bökeoğlu, 2008; Kesgin, 2006; Guo et al., 2010; Gençtürk, 2008; Akkuş, 2013; Gotch \& French, 2013) are consistent with the findings of this research. Since self-efficacy belief is a factor that affects the performance and success of the teachers (Babaoğlan \& Korkut, 2010), the high-level self-efficacy belief that preschool teachers have can be considered as a positive fact.

The findings of studies on classroom management skills of the teachers are consistent with the findings of this research as in the self-efficacy belief. In a study aiming to determine the belief and attitudes of preschool teacher candidates and teachers about classroom management, Keleş (2013) concluded that teachers' belief and attitude levels about classroom management were high. Denizel, Güven, and Cevher (2005) examined classroom management skills of preschool teachers and found that the vast majority of the teachers were at a sufficient level. In the study of Aküzüm and Altunhan (2017), in which the relationship between classroom management skills and mainstreaming competencies of 578 preschool teachers were examined, it was found that teachers considered themselves to be very competent in terms of classroom management skills. Regarding the opinions of the teachers about the classroom management skills reported in similar studies, they consider themselves to be an adequate level, which is in parallel with the findings of this study (Arın, Tunçer, \& Demir, 2017; Dinçer \& Akgün, 2015; Akın, 2006). As in the self-efficacy belief, the high level of classroom management skill perception (Aytekin, 2000), which is the most important factor in teachers' achievement of success from educational activities, can be interpreted as positive.

For the second sub-goal of the research, which was to reveal the differences among preschool teachers according to some demographic characteristics, difference statistics were computed by gender, age, seniority, education level, type of school graduated from, age group of children in their class, the number of children in their class, working time and status, and the availability of an assistant staff.

A difference in teachers' self-efficacy belief levels was observed by age; self-efficacy belief levels of teachers older than 40 years for parental involvement and classroom management were found to be significantly higher than those of teachers under the age of 30 years. For classroom management skills, the age of the teachers did not create any difference, but an increase was observed in the teachers' average classroom management skill score, as the age increased. As a result of the review of self-efficacy belief levels and classroom management skills of the teachers by seniority, no significant difference was observed, but as in the age variable, the average scores taken from the scale increased as the professional seniority increased. In this context, teachers show an increase in self-efficacy belief levels and classroom management skills with age and seniority. This result suggested that the increase in the seniority along with age, increased the experiences and practices of the teachers, and, thus, positively affected their self-efficacy belief and classroom management skills. In the study of Şenol and Ergün (2015) investigating self-efficacy belief of 161 preschool teacher candidates and 177 preschool teachers, it was concluded that teachers' self-efficacy belief levels increased as their age increased. Gökmen et al. (2016) found that self-efficacy belief levels of 31-40 year-old preschool teachers were higher than those of other age groups. Research showed that the increase in the age of teachers had a positive effect on self-efficacy belief levels (Kesgin, 2006; Say, 2005; Şenol Ulu, 2012).

Regarding relevant studies about classroom management skills, some studies found an increase in the skill level by age. The study of Zembat, Küsmüş, and Yılmaz (2018) on preschool teachers' creative thinking dispositions and classroom management, conducted with 199 preschool teachers, found that the averages of classroom management skills of the teachers who were older than 36 years were high. In a similar study by Dinçer and Akgün (2015), preschool teachers' classroom management skills were analyzed by some variables and found that the highest skill perception level was observed among teachers in the 35-39 years age group and those older than 40 years. Koçoğlu (2013) concluded that classroom teachers' classroom management skills were significantly higher in the 41-50 years age group. The findings of some studies (Özgün, 2008; Erol 2006; illgar, 2007; Durğun, 2010; Aküzüm \& Altunhan, 2017 are consistent with the findings of this research, but no significant difference observed in some studies, although there was an increase in the averages by age (Akkaya, 2011; Ekici et al., 2017; Yılmaz \& Aydın, 2015). 
Research showed that preschool teachers' self-efficacy perceptions increased as their seniority increased (Aslan \& Kalkan, 2018; Fives \& Buehl, 2009; Gençtürk \& Memiş, 2010; Kesgin, 2006; Say, 2005; Şenol \& Ergün, 2015; Şenol Ulu, 2012). In a study in which Wolters and Daugherty (2007) looked at 1024 teachers' self-efficacy belief levels by their professional experience and academic level, they concluded that the self-efficacy belief levels of the teachers with more professional experience were higher. Gökmen et al. (2016) revealed that teachers' self-efficacy belief levels increased as their professional experience increased. Conversely, there are studies indicating that there is no difference in the self-efficacy levels of teachers by seniority (Gömleksiz \& Serhatlıoğlu, 2013; Yılmaz et al., 2016). In their study examining preschool teachers' self-efficacy belief, Guo et al. (2010) reported a decrease in self-efficacy belief levels as professional experience increased. In the study in which Gotch and French (2013) looked at self-efficacy belief levels of 3000 primary school teachers, it was concluded that no difference existed in the self-efficacy levels of the teachers by their seniority. It is thought that seniority has a positive effect on self-efficacy belief as professional experiences and practices increase with increase in seniority, along with the positive effect of on-the-job trainings.

The review of the relevant studies in terms of the relationship between seniority and classroom management skills revealed various results parallel to the findings of this study (Dinçer \& Akgün, 2015; Özgan, Yiğit, Aydın \& Küllük, 2010). Sadık and Dikici Sığırtmaç (2016) showed that preschool teachers with a seniority of at least 10 years had higher classroom management skills. Aküzüm and Altunhan (2017) reported an increase in classroom management skills as the seniority of preschool teachers increases, and they explained the reason for this with the increase in knowledge, experiences, and practices, as well as the improvement of teachers' behavior towards children with experience. Ekici et al. (2017) reported that classroom management skills of preschool teachers with a seniority of at least 10 years were higher. Zembat et al. (2018) stated that there is an increase in the classroom management skills of preschool teachers as their seniority increases, and this was explained with the increase in classroom management skills occurring because of the increase in teachers' experiences and practices with time spent in the profession. Similarly, although there are studies indicating a positive relationship between professional seniority and classroom management skills (Erol, 2006; IIlgar, 2007; Illhan, 2011; Korkut, 2009; Özgün, 2008; Yeşilyurt \& Çankaya, 2008), some studies have concluded that there is no significant relationship between seniority and classroom management skills (Akkaya, 2011; Adiguzel, 2016; Cevher, 2005; Denizel Güven \& Durğun, 2010; Keleş, 2013; Nur, 2012; Turla, Şahin, \& Avcl, 2001; Yılmaz \& Aydın, 2015; Zembat et al., 2017). Gezgin (2009) found that the increase in the teachers' seniority affected classroom management skills negatively. In the study in which Toran and Gençgel Akkuş (2016) looked at the classroom management skills of preschool teachers according to some variables, they concluded that there was a negative relationship between seniority and classroom management skills, and classroom management skills decreased as seniority increased. Ekici et al. (2017) explained the reason for the differences in observations made in different studies to be a result of the differences in characteristics of the samples selected for the studies. Dinçer and Akgün (2015) explained the reason for the differences in results of the studies as follows: even though professional experience is an important factor, the extent to which the teacher improving him/ herself is an important factor as well.

No difference was observed by type of school graduated from. Similarly, Nur (2012), Turla et al. (2001), and Zembat et al. (2017) reported that classroom management skills of preschool teachers did not differ by the type of school graduated from. Conversely, Dinçer and Akgün (2015) reported that preschool teachers who graduated from formal education had higher class management skills than the ones who graduated from open education. Although the school from which the teacher graduated is a factor, it is thought that teachers' professional development is an important factor in the self-efficacy perceptions and classroom management skills as well.

It was found that there was a significant difference in both self-efficacy belief levels and classroom management skills of preschool teachers by the type of school that they worked in; the teachers working in preschool classes of primary schools had higher belief levels and skills. It was also found that the teachers who work in primary schools had significantly higher self-efficacy belief levels for the organization of learning environment, learning-teaching process, communication, parental involvement, planning, and classroom management than the teachers working in the kindergarten. Similarly, it was found that the teachers who work in primary schools had significantly higher levels of perceived professional skills than the teachers working in kindergarten. Tschannen-Moran and Woolfolk-Hoy (2001) claimed that external factors, such as the class size and equipment of the school, have more influence on the self-efficacy belief levels than the personal characteristics of teachers. In this regard, it is observed that teachers are influenced by the type of school they work in, which is an external factor.

Regarding studies examining self-efficacy belief levels of teachers by the type of school they work in, it is observed that there are different results. Gömleksiz and Serhatlıoğlu (2013) reported that self-efficacy perception levels of preschool teachers working in both kindergarten and primary schools were high, and there was no statistically significant difference among them. Kadim (2012) examined preschool teachers' self-efficacy belief levels in sports activities according to the school they work in, and concluded that the opinions of teachers working in kindergarten and primary schools differed in some cases, whereas they were similar in some cases. Gençtürk (2008) investigated the self-efficacy and job satisfaction of primary school teachers according to various variables, including type of school they work in, and reported that regarding the self-efficacy belief levels of teachers working in private and public schools, there was a difference in favor of private school teachers. The reason for this result was explained as follows: teachers needed to have a good performance in private schools for the continuity of their work, and private schools had better educational conditions. In this study, it is thought that teachers working in primary schools may be more motivated by the fact that they can observe the educational progress of the children in the primary school, which is the next education level.

Regarding the evaluation of the classroom management skills in terms of the type of school that teachers work in, Denizel-Güven and Cevher (2005) found a similar result in their research; they explained the reason for teachers working in primary schools having higher class management skills with the fact that they had shorter working hours, which had an impact on the teachers' level of burnout and affected their classroom management skills. However, Ekici et al. (2017) reported that teachers did not differ in classroom management skills by the type of school they work in. Zembat et al. (2017) concluded that the classroom management skills of the teachers working in kindergarten were higher than those of the preschool teachers working in primary schools, which is contrary to the research findings. The fact that the studies indicated different results showed that although the school type is an effective factor on both self-efficacy perceptions and class management skills of the teachers, its effect on the teacher may vary by the sample. 
Regarding the difference in self-efficacy perceptions and classroom management skills of the teachers according to the number of children in their class, it was found that the self-efficacy belief levels of the teachers with at most 15 children in the class were significantly higher than those with at least 16 children. For the teacher-child interaction skills, which is one of the sub-dimensions of classroom management, teacher-child interaction score was found to be significantly higher for teachers with at least 16 children in their class than those of teachers with at most 15 children. Dinçer and Akgün (2015) reported that class management skills of the teachers with at least 16 children in their class were higher. In his research on classroom teachers, Erol (2006) revealed that classroom management skills of the teachers with a large class size were also high, which supports the result of the current research. Similarly, the result indicating that "the classroom management skills of the teachers with higher class sizes are higher" is consistent with the findings of Yalçınkaya and Tombul (2002), Sirkeci (2010), and Zembat et al. (2018). However, some studies (Adıgüzel, 2016; Denizel-Güven, \& Cevher 2005; Durğun, 2010; Ekici et al., 2017; Metin et al., 2017; Toran \& Gençgel-Akkuş, 2016) reported that class size did not make a significant difference. Ilgar (2007) found that teachers' classroom management skills were negatively affected by the class size. Although it seems that the increase in class size makes classroom management more difficult (Ekici et al., 2017), it is thought that having at least 15 pupils in the class increases interaction among children and allows teachers to plan activities in a more diverse manner, thus facilitating classroom management (Dinçer \& Akgün, 2015)

No significant difference was observed in self-efficacy belief levels and classroom management skills of teachers by working status. Ekici et al. (2017) also reported that there was no difference in classroom management skills of teachers by working status. Dinçer and Akgün (2015) found a significant difference in favor of permanent teachers; they reported that this may be due to the fact that permanent teachers felt that they belong to the institution. Although a teacher's working status is an important factor, the fact that there is no difference in the results of the study suggested that teachers' classroom management skills are related to self-development and their love for the profession (Ekici et al., 2017).

Regarding availability of assistant staff, significant differences were observed in both classroom management skills and self-efficacy belief levels. It was found that teachers with assistant staff have significantly higher self-efficacy belief levels in organizing learning environments, learning-teaching process, communication, parental involvement, planning, and classroom management than those without assistant staff. Regard ing classroom management skills, it was found that teachers with assistant staff have significantly higher perceived professional skills than those who do not. Conversely, Dinçer and Akgün (2015) concluded that the availability of assistant staff in the classroom had no effect on the classroom management skills of teachers. The fact that there is a significant difference by availability of assistant staff in the research suggested the idea that having assistant staff makes teachers feel more comfortable in the classroom, and consequently to be more effective in using their knowledge and skills.

Regarding the relationship between teachers' self-efficacy belief and classroom management skills, a positive and moderate relationship was observed. It was found that there were positive and moderate relationships between teachers' perceived classroom management skills and planning, classroom management, organization of the learning environment, communication, learning-teaching process, and parental involvement self-efficacy belief. The evaluation of this relationship by the sub-dimensions of classroom management skills showed that there was a positive and strong relationship between pre- school teachers' perceived professional skills and self-efficacy belief; there were positive and moderate relationships between professional skills and parental involvement, planning, learning-teaching process, communication, classroom management, and organization of learning environment, which are sub-dimensions of self-efficacy belief.

It was found that there was a positive but weak relationship between teacher-child interaction, which is a sub-dimension of classroom management skills, and self-efficacy belief; whereas there are positive and weak relationships between teachers' perceived teacher-child interaction skills and self-efficacy belief for teaching process and organizing the learning environment, which are among the sub-dimensions of self-efficacy belief. Babaoğlan and Korkut (2010) found a moderate relationship between teachers' self-efficacy belief and classroom management skills, supporting the findings of this study. Similarly, Savran and Çakıroğlu (2003) found that pre-service teachers had a positive relationship between effective teaching belief and class management skills. In this study, the moderate relationship between preschool teachers' self-efficacy belief and classroom management skills indicates that if one of them increases, the other would increase as well, whereas a decrease in one will cause a decrease in the other.

As a result, it was observed that preschool teachers' self-efficacy belief and classroom management skills were affected by teachers' age, seniority, type of school they work in, and the number of children in the class; these variables played a role in teachers' belief levels and skills. The moderate positive relationship between teachers' self-efficacy belief and classroom management skills showed that the qualities achieved in these two areas have an effect on each other.

Regarding the results of the study, it can be suggested that in-service training programs should be organized to develop the self-efficacy belief and classroom management skills of new teachers working in kindergarten. Arrangements about preschool teachers to have auxiliary staff in the classrooms are recommended. In addition, it may be suggested that different scales be developed to determine the effects of preschool teachers' personal characteristics and educational environment, as well as to develop intervention programs on the possible negative effects of the variables.

\section{Limitations and Directions for Future Research}

This study extended the scope of research about teachers' self-efficacy belief and classroom management skills. However, the research also has some conceptual and methodological limitations. First, conceptually, in Turkey there are limited number of studies of this nature conducted in preschools; thus, the findings were mostly discussed with the results obtained from other levels of education. Considering the educational environment and developmental differences of children, it should be noted that teachers' self-efficacy belief and classroom management skills may change. There are also methodological limitations. The study sample consisted of 274 teachers working in a certain province in Turkey. Teachers' belief levels and skills are thought to change by the regions in which they work. For future studies, it is important to work with a larger sample in various other parts of Turkey to confirm the findings of the current study. Because selecting elements process from the population to examine the study sample, future studies may have a chance to generalize their results back to the population from which they were picked. Another methodological limitation is the use of quantitative research. Teachers filled the scales according to their own opinions. In the future, more in-depth studies using both qualitative and quantitative research methods can be conducted to further confirm the findings. Additionally, research on how the perceptions of self-efficacy belief and classroom manage- 
ment skills of teachers whose belief and skills have been identified are reflected in classroom practices.

\section{References}

Açıkgöz, K.Ü. (2003). Etkili öğrenme ve öğretme. İzmir: Eğitim Dünyası.

Adıgüzel, I. (2016). Okul öncesi öğretmenlerinin sınıf yönetimi becerileri ile tükenmişlik düzeyleri arasındaki ilişki. Unpunlished Master Thesis, Recep Tayyip Erdoğan Üniversitesi Sosyal Bilimler Enstitüsü, Rize.

Akgün, E., Yarar, M., \& Dinçer, Ç. (2011). Okul öncesi öğretmenlerinin sınıf içi etkinliklerde kullandıkları sınıf yönetimi stratejilerinin incelenmesi. Pegem Eğitim ve Ögretim Dergisi, 1(3), 1-9.

Akın, U. (2006). Öğretmenlerin sınıf yönetimi becerileri ile iş doyumları arasındaki ilişki. Unpunlished Master Thesis, Gaziosmanpaşa Üniversitesi Sosyal Bilimler Enstitüsü, Tokat.

Arın, E., Tunçer, B. K., \& Demir, M. K. (2017). Primary school teachers' views on constructive classroom management. International Electronic Journal of Elementary Education, 8(3), 363-378.

Akkaya, M. (2011). Sınıf Öğretmenlerinin sınıf yönetimi becerileri ile mizah tarzları arasındaki ilişkinin incelenmesi (istanbul ili Şişli ilçesi örneği). Unpunlished Master Thesis, Yeditepe Üniversitesi Sosyal Bilimler Enstitüsü, İstanbul.

Akkuş, Z. (2013). Sosyal bilgiler öğretmen adaylarının öz-yeterlik inanç düzeylerinin belirlenmesi. Dicle Üniversitesi Ziya Gökalp Ĕgitim Fakültesi Dergisi, 20, 102-116.

Aküzüm, C. \& Altunhan, M. (2017). Okul öncesi öğretmenlerinin sınıf yönetimi becerileri ile kaynaştırma eğitimi yeterliklerinin incelenmesi. Dicle University Journal of Ziya Gokalp Education Faculty, (31), 779-802.

Aslan, M. \& Kalkan, H. (2018). Öğretmenlerin özyeterlik algılarının analizi. Bingöl Üniversitesi Sosyal Bilimler Enstitüsü Dergisi, 8(16), 477-494.

Aytekin, H. (2000). Sınıf yönetimi ve disiplinle ilgili kurallar geliştirme ve uygulama. In L. Küçükahmet (Ed.), Sınıf yönetimi (ss. 71-81). Ankara: Nobel.

Babaoğlan, E. \& Korkut, K. (2010). Sınıf öğretmenlerinin öz yeterlik inançları ile sınıf yönetimi beceri algıları arasındaki ilişki? Inönü Üniversitesi Eğitim Fakültesi Dergisi, 11(1), 1-19.

Bandura, A. (1977). Self-efficacy: Toward a unifying theory of behavioral change. Psychological Review, 84(2), 191215.

Başal, H. (2005). Okul öncesi eğitim. İstanbul: MORPA.

Büyükduman, F. İ. (2006). Ingilizce öğretmen adaylarının ingilizce ve öğretmenlik becerilerine ilişkin öz-yeterlik inançları ve arasındaki ilişki. Unpunlished Master Thesis, Yıldız Teknik Üniversitesi Sosyal Bilimler Enstitüsü, İstanbul.

Büyüköztürk, S., Kılıç-Çakmak, E., Akgün, Ö., Karadeniz, S., \& Demirel, F. (2018). Eğitimde Bilimsel Araştırma Yöntemleri. Ankara: Pegem.
Carlson, J. S., Tiret, H. B., Bender, S. L., \& Benson, L. (2011). The influence of group training in the Incredible Years Teacher Classroom Management Program on preschool teachers' classroom management strategies. Journal of Applied School Psychology, 27(2), 134154.

Degol, J. L. \& Bachman, H. J. (2015). Preschool teachers' classroom behavioral socialization practices and low-income children's self-regulation skills. Early Childhood Research Quarterly. 31(2), 89-100.

Demirtaş, H., Cömert, M., \& Özer, N. (2011). Öğretmen adaylarının öz yeterlik inançları ve öğretmenlik mesleğine ilişkin tutumları. Eğitim ve Bilim Dergisi, 36(159), 96111.

Denizel Güven, E. \& Cevher, F. N. (2005). Okul öncesi öğretmenlerinin sınıf yönetimi becerilerinin çeşitli değişkenler açısından incelenmesi. Pamukkale Üniversitesi Eğitim Fakültesi Dergisi, 18(2), 1-22.

Dinçer, Ç. \& Akgün, E. (2015). Okul öncesi öğretmenleri için sınıf yönetimi becerileri ölçeğinin geliştirilmesi ve öğretmenlerin sınıf yönetimi becerilerinin çeşitli değişkenlerle ilişkisi. Eğitim ve Bilim, 40(177), 187 201.

Duman, B. (2008). Öğrenme-öğretme sürecindeki entelektüel şizofrenizm. Türk Eğitim Bilimleri Dergisi, 6(2), 287-321.

Durğun, B. (2010). Sınıfında kaynaștırma öğrencisi bulunan sını öğretmenlerinin, sınıf yönetimi becerilerinin çeşitli değişkenler açısından incelenmesi (Sancaktepe ilçesi Örneği). Unpunlished Master Thesis, Yeditepe Üniversitesi Sosyal Bilimler Enstitüsü, İstanbul.

Ekici, F. Y., Günhan, G., \& Anılan, Ş. (2017). Okul öncesi öğretmenlerinin sınıf yönetimi becerileri. Uluslararası Bilimsel Araştırmalar Dergisi (IBAD), 2(1), 48-58.

Erol, Z. (2006). Sınıf Öğretmenlerinin Sınıf Yönetimi Uygulamalarına Illişkin Görüşleri. Yayımlanmamış Yüksek Lisans Tezi, Afyon Kocatepe Üniversitesi, Sosyal Bilimler Enstitüsü, Afyonkarahisar.

Erol, O, Özaydın, B., \& Koç, M. (2010). Sınıf yönetiminde karşılaşılan olaylar, öğretmen tepkileri ve öğrenciler üzerindeki etkileri: Unutulmayan sınıf anılarının analizi. Kuram ve Uygulamada Eğitim Yönetimi Dergisi. 16(1), 25-47.

Filcheck, H. A., McNeil, C. B., Greco, L. A., \& Bernard, R. S. (2004). Using a whole-class token economy and coaching of teacher skills in a preschool classroom to manage disruptive behavior. Psychology in the Schools, 41(3), 351-361.

Fives, H. \& Buehl, M., M. (2009). Examining the factor structure of the teachers' sense of efficacy scale. The Journal of Experimental Education, 78(1), 118-134.

Gençtürk, A. (2008). Ilköğretim okulu öğretmenlerinin öz-yeterlik algıları ve iş doyumlarının çeşitli değişkenler açısından incelenmesi. Unpunlished Master Thesis, Zonguldak Karaelmas Üniversitesi Sosyal Bilimler Enstitüsü, Zonguldak.

Gençtürk, A. \& Memiş, A. (2010). illköğretim okulu öğretmenlerinin öz-yeterlik algıları ve iş doyumlarının demografik faktörler açısından incelenmesi. ilköğretim Online, 9(3), 1037-1054. 
Gettinger, M. \& Kohler, K.M. (2006). Process-outcome approaches to classroom management and effective teaching. In C.M. Evertson \& C.S. Weinstein (Eds.) Handbook of classroom management: Research, practice, and contemporary issues (73-96). Mahwah, NJ: Lawrence Erlbaum.

Gezgin, N. (2009). Okul öncesi öğretmenlerinin kullandıkları sınıf yönetimi stratejileri. Unpunlished Master Thesis, Uludağ Üniversitesi Sosyal Bilimler Enstitüsü, Bursa.

Gibson, S. \& Dembo, M. H. (1984). Teacher efficacy: A construct validation. Journal of Educational Psychology, 76(4), 569-582

Goddard, R. D. \& Goddard, Y. L. (2001). Multilevel analysis of the relationship between teacher and collective efficacy in urban schools. Teaching and Teacher Education, $17,807-818$.

Goddard, R. D., Hoy, W. K., \& Woolfolk, A. (2000). Collective teacher efficacy: its meaning, measure, and effect on student achievement. American Education Research Journal, 37, 479-507.

Gotch, C. M., \& French, B. F. (2013). Elementary teachers' knowledge and self-efficacy for measurement concepts. The Teacher Educator, 48, 46-47

Gökmen, A. H., Deveci, H., Bingöl, K., Bekir, H., Temel, Z. F., \& Kanat, K. K. (2016). Okul öncesi öğretmenlerinin high scope yaklaşımı inançları ile özyeterlik inançları arasındaki ilişkinin incelenmesi. Kastamonu Education Journal, 24(5), 2481-2500.

Gömleksiz, M. N. \& Serhatlıoğlu, B. (2013). Okul öncesi öğretmenlerinin öz-yeterlik inançlarına ilişkin görüşleri. Electronic Turkish Studies, 8(7), 201-221.

Guo, Y., Piasta, S. B., Justice, L. M., \& Kaderavek, J. N. (2010). Relations among preschool teachers' self-efficacy, classroom quality and children's language and literacy gains. Teaching and Teacher Education, 26, 1094-1103.

Henson, R. K. (2001). The effects of participation in teacher research on teacher efficacy. Teaching and Teacher Education, 17(7), 819-836.

İlgar, L. (2007). Illköğretim öğretmenlerinin sınıf yönetimi becerileri üzerine bir araştırma. Unpunlished Master Thesis İstanbul Üniversitesi Eğitim Bilimleri Enstitüsü, İstanbul.

İlhan, S. (2011). Ilköğretim sını öğretmenlerinin uygulamaya dayalı öğretim teknolojileri ve materyal geliştirme becerileri ile sınıf yönetimi becerileri arasındaki ilişki. Unpunlished Master Thesis, Afyon Kocatepe Üniversitesi Sosyal Bilimler Enstitüsü, Afyon.

Jacobson, L. (2003). Early Years. Education Week, 23(15), 6-11.

Justice, L. M., Mashburn, A. J., Hamre, B. K., \& Pianta, R. C. (2008). Quality of language and literacy instruction in preschool classrooms serving at-risk pupils. Early Childhood Research Quarterly, 23, 51-68.

Kadim, M. (2013). Okul öncesi öğretmenlerinin oyun etkinliklerine ilişkin öz-yeterliklerinin görev yapılan okul türüne göre incelenmesi. Nevşehir $\mathrm{Hacl}$ Bektaş Veli Üniversitesi SBE Dergisi, 2(1), 1-21.
Kagan, D. M. (1992). Implications of research on teacher belief. Educational Psychologist, 27, 65-90.

Karasar, N. (2003). Bilimsel Araştırma Yöntemi. Ankara: Nobel.

Keleş, O. (2013). Okul öncesi öğretmen adaylarının ve okul öncesi ögrretmenlerinin sınıf yönetimine ilişkin tutum ve inançlarının incelenmesi. Unpunlished Master Thesis, Çukurova Üniversitesi Sosyal Bilimler Enstitüsü, Adana.

Keskin, E. (2006). Okul öncesi eğitim öğretmenlerinin öz-yeterlik düzeyleri ile problem çözme yaklaşımlarını kullanma düzeyleri arasındaki ilişkinin incelemesi (Denizli ili örneği). Unpunlished Master Thesis, Pamukkale Üniversitesi Sosyal Bilimler Enstitüsü, Denizli.

Koçoğlu, A., M. (2013). Ilkokullardaki sınıf öğretmenlerinin sınıf yönetimi becerilerinin çok boyutlu olarak incelenmesi (İstanbul ili Sancaktepe örneği). Unpunlished Master Thesis, Yeditepe Üniversitesi Sosyal Bilimler Enstitüsü, İstanbul.

Korkut, K. (2009). Sınıf öğretmenlerinin öz yeterlik inançları ile sınıf yönetimi beceri algıları arasındaki ilişki. Unpunlished Master Thesis, Mehmet Akif Ersoy Üniversitesi Sosyal Bilimler Enstitüsü, Burdur.

Lorsbach, A. \& Jinks, J. (1999). Self-efficacy theory and learning environment. Learning Environments Research, 2(2), 157-167.

Marzano, R. J. (2003). What works in schools: Translating research into action. Alexandria, VA: ASCD.

Marzano, R. J., Marzano, J. S., \& Pickering, D. J. (2003). Classroom Management that works. Alexandria. V.A: Association for Supervision and Curriculum Development.

Meehan, M. L., Cowley, K. S., Schumacher, D., Hauser, B., \& Croon, N. D. (2003). Classroom environment, instructional resources and teaching differences in high performing Kentucky schools with achievement gaps. Paper presented at the 12th annual CREATE National Evaluation Institute. Louisville, KY. July 24-26, 2003. AEL, Inc.

Metin, Ş., Aydoğan, Y., Kavak, Ş., \& Mercan, Z. (2017). Effects of classroom management profiles of pre-school teachers on social skills and problem behaviors of children. Journal of Current Researches on Social Sciences, 7(1), 517-534.

Midgley, C., Feldlaufer, H., \& Eccles, J. S. (1989). Change in teacher efficacy and student self-and task-related beliefs in mathematics during the transition to junior high school. Journal of educational Psychology, 81(2), 247-258.

Miller, A. (2003). Teachers, parents and classroom behavior-A psychosocial approach. London: Open University.

Nur, I. (2012). Anaokullarında örgüt iklimi ile öğretmenlerin sınıf yönetimi becerileri arasındaki ilişkinin incelenmesi (Malatya ili örneği). Unpunlished Master Thesis, Inönü Üniversitesi Eğitim Bilimleri Enstitüsü, Malatya.

Oliver, R. M., Wehby, J. H., \& Reschly, D. J. (2011). Teacher classroom management practices: Effects on disruptive or aggressive student behavior. Campbell Systematic Reviews, 4, 1-55. 
O'Neill, S. C. \& Stephenson, J. (2011). The measurement of classroom management self-efficacy: a review of measurement instrument development and influences. Educational Psychology: An International Journal of Experimental Educational Psychology, 31(3), 261-299.

Özdemir, İ. E. (2004). Sınıf ortamında istenmeyen davranışlar. In Erçetin ve Ç. Özdemir (Ed.). Sınıf yönetimi (ss. 269295). Ankara: Asil.

Özgan, H., Yiğit, C., Aydın, Z., \& Küllük, M. C. (2010). illköğretim okulu öğretmenlerinin sınıf yönetimine ilişkin algılarının incelenmesi ve karşılaştırılması. Gaziantep University Journal of Social Sciences, 10(1), 615-635.

Özgün, E. (2008). ilköğretim birinci kademe öğretmelerinin iş motivasyonları ile sınıf yönetim becerilerini algılama düzeyleri arasındaki ilişki. Unpunlished Master Thesis, Yeditepe Üniversitesi Sosyal Bilimler Enstitüsü, İstanbul.

Öztürk, B. (2002). Sınıfta istenmeyen davranışların önlenmesi ve giderilmesi. In E. Karip (Ed.). Sinıf yönetimi (ss. 144-156). Ankara: Pegem A.

Pianta, R.C. (1997). Adult-child relationship processes and early schooling. Early Education and Development, 8, $11-26$.

Piwowar, V. Thiel, F., \& Ophardt, D. (2013). Training in service teachers' competencies in classroom management, a quasi-experimental study with teachers of secondary schools. Teaching and Teacher Education, 30, 1-12.

Sadık, F. \& Dikici Sığırtmaç, A. (2016). Okul öncesi öğretmenlerinin sınıf yönetim becerileri ve uygulamalarına yönelik görüşlerinin incelenmesi. Electronic Turkish Studies, 11(14), 631-664.

Savran, A. \& Çakıroglu, J. (2003). Differences between elementary and secondary preservice science teachers' perceived efficacy beliefs and their classroom management beliefs. The Turkish Online Journal of Educational Technology, 2(4), 15-20.

Say, M. (2005). Fen bilgisi öğretmenlerinin öz yeterlik inançları. Unpunlished Master Thesis, Marmara Üniversitesi Eğitim Bilimleri Enstitüsü, İstanbul.

Schunk, D. H. (1991). Self-efficacy and academic motivation. Educational Psychologist, 26(34), 207-331.

Sirkeci, B. (2010). Özel ve devlet ilköğretim okulları birinci kademesindeki öğretmenlerin, sınıf yönetiminde karşılaştıkları disiplin sorunları ve yaklaşım biçimleri. Unpunlished Master Thesis. Fırat Üniversitesi Sosyal Bilimler Enstitüsü, Elazı̆̆.

Sucuoğlu, B. (2008). Okul öncesi sınıflarda kaynaştırma ve sınıf yönetimi. Çoluk Çocuk Dergisi, 40-45.

Şahin-Sak, i. T., Sak, R., \& Tezel-Şahin, F. (2018). Preschool teachers' views about classroom management models. Early Years, 38(1), 35-52.

Şenol Ulu, F.B. (2012). Okul öncesi öğretmen adayları ile okul öncesi ögrretmenlerinin öğretmenlik mesleğine yönelik öz yeterlik inançlarının karşılaştırılması. Unpunlished Master Thesis, Afyon Kocatepe Üniversitesi Sosyal Bilimler Enstitüsü, Afyon.
Şenol, F. B. \& Ergün, M. (2015). The comparison of teacher self-efficacy beliefs between pre-service preschool teachers and preschool teachers. Journal of Theoretical Educational Science, 8(3), 297-315.

Tal, C. (2010). Case studies to deepen understanding and enhance classroom management skills in preschool teacher training. Early Childhood Education Journal, 38(2), 143-152.

Tepe, D. \& Demir, K. (2012). Okul öncesi öğretmenlerinin öz-yeterlik inançları ölçeği. Abant İzzet Baysal Üniversitesi Eğitim Fakültesi Dergisi, 12(2), 137-158.

Toran, M. (2019). Does sense of efficacy predict classroom management skills? An analysis of the pre-school teacher's professional competency. Early Child Development and Care, 189(8), 1271-1283.

Toran, M. \& Gençgel Akkuş, H. (2016). Okul öncesi öğretmenlerinin sınıf yönetimi becerilerinin değerlendirilmesi: KKTC Örneği. Kastamonu Eğitim Dergisi, 24(4), 2041 2056.

Tschannen-Moran, M. \& Woolfolk-Hoy, A. (2001). Teacher efficacy: Capturing an elusive construct. Teaching and Teacher Education, 17(7), 783-805.

Turla, A., Şahin, T. F., \& Avcl, N. (2001). Okulöncesi öğretmenlerinin fiziksel şartlar, program, yöntem, teknik, sınıf ve davranış yöntemi sorunlarının bazı değişkenlere göre incelenmesi. Milli Ĕgitim Dergisi, 151, 95-101.

Üstüner, M., Demirtaş, H., Cömert, M., \& Özer, N. (2009). Ortaöğretim öğretmenlerinin öz-yeterlik algıları secondary school teachers' self-efficacy beliefs. Mehmet Akif Ersoy Üniversitesi Eğitim Fakültesi Dergisi, 9(17), 1-16.

Woolfolk-Hoy, A. (2000). Changes in teacher efficacy during the early years of teaching. Paper presented at the American Educational Research Association. New Orleans: LA.

Woolfolk-Hoy, A. \& Hoy, W. K. (1990). Prospective teachers' sense of efficacy and beliefs about control. Journal of Educational Psychology, 82(1), 81-91.

Wolters, C. A. \& Daugherty, S. G. (2007). Goal structures and teachers' sense of efficacy: Their relation and association to teaching experience and academic level. Journal of Educational Psychology, 99, 181-193.

Yalçınkaya, M. \& Tonbul, Y. (2002). Illköğretim okulu sınıf öğretmenlerinin sınıf yönetimi becerilerine ilişkin algı ve gözlemleri. Ege Eğitim Dergisi, 1(2), 96-103.

Yeşilay Daşıran, T. (2013). Okul öncesi eğitimde etkili sınıf yönetimi becerilerini geliștirmeye yönelik hazırlanan eğitimin etkililiğinin incelenmesi. Unpunlished Master Thesis, Ankara Üniversitesi Eğitim Bilimleri Enstitüsü, Ankara.

Yeşilyurt, E. \& Çankaya, i. (2008). Sınıf yönetimi açısından öğretmen niteliklerinin belirlenmesi. Elektronik Sosyal Bilimler Dergisi, 7(23), 274-295.

Yılmaz, Z. N. \& Aydın, Ö. (2015). İlköğretim öğretmenlerinin sınıf yönetimi becerilerine ilişkin algılarının çeşitli değişkenler açısından incelenmesi. Mersin Üniversitesi Ĕgitim Fakültesi Dergisi, 11(1), 148-164. 
Yılmaz, K. \& Çokluk-Bökeoğlu, Ö. (2008). İlköğretim okulu öğretmenlerinin yeterlik inançları. Ankara Üniversitesi Eğitim Bilimleri Fakültesi Dergisi, 41(2), 143-167.

Yılmaz, M., Gerçek, C., Köseoğlu, P., \& Soran, H. (2006). An analysis of the self-efficacy beliefs about computers of the biology student teachers in Hacettepe university. $\mathrm{HU}$ Journal of Education, 30, 278-28.

Yılmaz, M., Köseoğlu, P., Gerçek, C., \& Soran, H. (2004). Öğretmen öz-yeterlik inancı. Bilim ve Aklın Aydınlığında Eğitim Dergisi, 5(58), 50-54.

Yılmaz, E., Tomris, G., \& Kurt, A. A. (2016). Okul öncesi öğretmenlerinin özyeterlik inançları ve teknolojik araç-gereç kullanımına yönelik tutumları: Balıkesir ili örneği. Anadolu Üniversitesi Eğitim Bilimleri Enstitüsü Dergisi, 6(1), 1-26.

Zembat, R., Küsmüş, G. İ., \& Yılmaz, H. (2018). Okul öncesi öğretmenlerinin yaratıcı düşünme eğilimleri ve sınıf yönetimleri. Serkan Dinçer (Editör). Değişen dünyada eğitim (67-80). Ankara: Pegem A.

Zembat R., Tunçeli, H.i.., \& Akşin Yavuz, E. (2017). Okul öncesi öğretmenlerinin sınıf yönetimi becerileri ile problem çözme becerileri arasındaki ilişkinin incelenmesi. Ahi Evran Üniversitesi Kırşehir Eğitim Fakültesi Dergisi, 18(3), 24-43. 